\title{
Health Status Assessment of a Population of Asylum Seekers in Northern Italy
}

Luca Manfredi ( $\square$ luca.manfredi254@edu.unito.it)

University of Padova https://orcid.org/0000-0002-6530-4326

\section{Veronica Sciannameo}

University of Padua

\section{Cinzia Destefanis}

University of Turin

\section{Marta Prisecaru}

University of Turin

\section{Giorgia Cossu}

University of Turin

Roberto Gnavi

Regional Health Service ASLTO3

Alessandra Macciotta

University of Turin

\section{Alberto Catalano \\ University of Turin}

Roberto Raffaele Pepe

Italian Red Cross

\section{Carlotta Sacerdote}

University of Turin

\section{Fulvio Ricceri}

University of Turin

\section{Research}

Keywords: Migration, migrants health, asylum seekers, migrants diseases, migration in Italy, antimicrobial resistance, vaccination

Posted Date: December 21st, 2021

DOI: https://doi.org/10.21203/rs.3.rs-1096434/v1

License: (9) This work is licensed under a Creative Commons Attribution 4.0 International License. 
Page $2 / 21$ 


\section{Abstract}

\section{Background}

Since 2011 Italy has faced an extraordinary increase in migrants arrivals, mainly from the Mediterranean route, one of the world's most dangerous journeys. The purpose of the present article is to provide a comprehensive picture of the migrants' health status in the centre "T.Fenoglio", Settimo Torinese (Turin, Italy).

\section{Methods}

A retrospective cross-sectional study was conducted using data collected from June 2016 to May 2018 on adult migrants (>18 years) from Africa, East and Middle East. Data was collected through the migrants' medical records. Descriptive statistics were performed on socio-demographic variables. The diagnosed diseases were anonymously registered and classified according to the International Classification of Primary Care (ICPC-2).

Conditional Inference Trees were used to perform a descriptive analysis of the sample and to detect the covariates with the strongest association with the outcome variables Disease on Arrival and ICPC-2 for diseases on arrival.

\section{Results}

Analyzed observations were 9857. 81.8\% were men, median age was 23 (Interquartile range= 20.0-27.4). $70.3 \%$ of the sample came from Sub-Saharan Africa. 2365 individuals (24\%) arrived at the center with at least one disease. On arrival, skin $(27.71 \%)$, respiratory $(14.46 \%)$, digestive $(14.73 \%)$ and generic diseases $(20.88 \%)$ were the most frequent. During the stay respiratory diseases were the most common $(25.70 \%)$. The highest probability of arriving with a disease occurred in 2018 and in the period SeptemberNovember 2016, in particular for people from the Horn of Africa. During this period and also in the first half of 2017, skin diseases were the most reported. In quarters with lower prevalence of diseases on arrival the most common disease code was generic for both men and women.

\section{Conclusions}

Horn of Africa was the most troubled area with severe conditions frequently reported regarding skin diseases, in particular scabies. 2018 was the most critical year, especially for migrants from Horn of Africa and Sub-Saharan Africa.

A better understanding of the health status of asylum seekers is an important factor to determine a more efficient reception and integration process and the better allocation of economic resources in the context of migrants' health care.

\section{Introduction}


According to the United Nations High Commissioner for Refugees (UNHCR) (mid 2020) forcibly displaced people have passed 80 million worldwide, as a result of conflicts, persecutions and other causes. The largest number ever according to available data.[1] Asylum seekers (AS), individuals who are seeking international protection,[2] are 16 million over the last decade, two thirds of which in the last five years.[1] In recent years, Europe has faced the greatest migratory challenge since World War II.

A first peak was reached in 2014 with the Ukraine conflict, while the second in 2015, due to the Syrian war worsening. Moreover, an increasing number of people started to cross the Mediterranean Sea.[1]

In the first 10 months of 2020, asylum applications in the EU (390 000) dropped by 33\% compared to the same period of 2019. The Mediterranean route remains one of the most dangerous, with 1754 people reported dead or missing in 2020.[3]

The largest group of ASs consists of Syrians in 7 out of 27 countries of EU-27. Three quarters of them are less than 35 years (47\% within the range 18-34), 30\% are children. Men account for $61.9 \%$.[4]

As a consequence of the Arab Spring (2011), Italy has faced an extraordinary increase in arrivals, mainly from the Mediterranean route (181000 in 2016). Since 2017 the trend has reversed (119000), down to 34 154 arrivals in $2020 .{ }^{5}$ Since 2017 the largest number of migrants in Italy came from Nigeria, Guinea, Ivory Coast and Mali. 74\% of this population was composed of men. In 2019 the overall number is decreased and $21 \%$ is from Tunisia ( $75 \%$ men).[5]

In agreement with the Dublin Regulation if an AS illegally crosses an EU member state border, the application examination is under responsibility of the first country of entry.[6]

The European Agenda on Migration, adopted in May 2015, provides for the relocation of migrants within the European Union based on a quota system. This system imposes a strict division of migrants into two categories: economic migrants and refugees[6] (people who meet the eligibility criteria under the national legislation[2]). Until 2018 the Italian law was based on bilateral agreements with foreign countries, to contain illegal migration. Migrants who entered Italy asking for refugee status were hosted in 19 HUBs across the country. In a second stage, they were taken in charge by a second level system (SPRAR: Asylum Seekers and Refugees protection system): applicants for refugee status were given temporary documents, language and professional courses and documentation to work. [7] In more recent years, Italian legislation was amended several times (refer to supplementary material for details).

The main aim of the present study was to provide a description of the health profile of ASs hosted in the HUB of Piedmont Region: the centre of Settimo Torinese, Turin. Secondly, to analyze factors determining the health status of this population.

\section{Methods}


The present work is a retrospective cross-sectional study on data collected in the period June 1, 2016 May 31, 2018, through medical records of ASs hosted in the centre "T. Fenoglio", Settimo Torinese (Turin, Italy). The centre has been one of the Italian Red Cross structures involved in the reception plan for ASs as a regional HUB. For unaccompanied minors a different path was determined on arrival.

The centre team was composed of two physicians, a nurse and two psychologists. Weekly visits by specialist physicians were planned. In case of serious health conditions transport to the hospital was provided.

During this time, 15567 people were admitted to the centre. A medical examination was performed for every subject on arrival. Information about personal data, date of arrival at the centre, date of leaving, health status data, medical history, any diagnoses, treatments and hospitalizations were collected. Moreover, the diseases diagnosed during the first examination or by other exams performed during the stay were anonymously registered and classified according to the International Classification of Primary Care, 2nd edition (ICPC-2)[8]. In case of multimorbidity, up to 3 diseases have been considered.

Descriptive statistics were used to present socio-demographic characteristics (Area of origin, Age, Gender, Time of Arrival) and the distribution of the diseases. Area of origin was divided into six regions: SubSaharan Africa (SSA), Northern Africa (NA), Horn of Africa (HoA), Central-Southern Africa (CSA), Middle East, East.

Age was categorized in classes: 18-24, 25-34, 35+. Minors (436, 4.67\%) were excluded from the analysis as they were not a representative sample of this subpopulation.

Time of arrival was categorized in quarters: December-February (Q1), March-May (Q2),

June-August (Q3), September-November (Q4), for each available year.

Results of categorical variables were presented as frequencies ( $n$ ) and percentages (\%); continuous ones in terms of medians and interquartile ranges (IQRs).

Conditional Inference Trees were used to perform a descriptive analysis of

the sample and to detect the covariates with the strongest association with the outcome variables (see supplementary material for algorithm details).[9]

In our study, four of these models were performed, besides the sample has been previously split according to the variable gender, taking into account gender specific diseases. The first outcome variable was Diseases on Arrival (DoA). In the second model we used a categorical response variable (ICPC on Arrival) having five categories: the four most frequent ICPC-2 classes of diseases ( $A=$ generic,$D=$ digestive, $R=$ respiratory, $S=$ skin) and the additional category Other, that includes all remaining ICPC-2 codes (in case of multimorbidity the most severe disease was considered). Similar models were performed regarding Diseases after Arrival and ICPC-2 for diseases after Arrival as outcome variables

The A code states for "General and Unspecified", which includes many diseases from infections like Tuberculosis, Malaria, Measles and Chickenpox to generic and psychological disorders like fever, 
weakness, body pain, fear of death, fear of various diseases, unspecified trauma, poisoning or adverse effects of medical treatments and others.

The a level was set to $1 \%$.

. In addition, Multiple logistic regression models were performed using the same variables to assess trees results (supplementary material).

Analyses were conducted using R (V 3.6.2)[35] and SAS (V 9.04).

\section{Results}

At the time of the analysis many records were found to be incomplete or even missing and the sample was reduced to 9857 observations.

As shown in Table 1, 81.8\% of the ASs were men. Median age was 23 years (range= $18-73$, IQR $=(20.0$ $27.4))$. The most common age group was $18-24$ (62.80\%).

Data was collected since Q3/16. The number of arrivals to the center was higher in 2016 ( $\max$ in Q4/16, $\mathrm{n}=3803,38.58 \%$ ), and gradually declined during the following years. Length of stay was available for 6 938 observations: median value was 11 days (IRQ $=4-28)$, and $77 \%$ of the sample time of stay was less than a month.

Most of the sample came from Africa, in particular from SSA ( $n=6929,70.31 \%)$. Non-African arrivals were from the Middle East $(n=568,5.76 \%)$ and East $(n=457,4.64 \%)$.

2365 individuals (24\%) arrived at the center with at least one disease, while 1684 (17.09\%) developed at least one during their stay.

On arrival, the most frequent diseases were skin $(27.71 \%)$, respiratory $(14.46 \%)$, digestive $(14.73 \%)$ and generic diseases (20.88\%) (Table 2), whereas during the stay diseases of class $\mathrm{R}$ increased considerably (25.70\%) and a notable decrease occurred for class S (12.29\%) (Table 3). Hospitalizations were 232, classified using the ICPC- 2 method as well. The most common causes were generic causes $(n=35$, $15.09 \%)$, respiratory diseases $(n=28,12.07 \%)$ and pregnancy issues $(n=34,14.66 \%)$. Out of the total number of women, pregnancies were 198 (on arrival) (11.06\%).

Prevalence of scabies was high for African arrivals: 882 cases detected, of which $39.46 \%$ from HoA and $57.82 \%$ from SSA.

\subsection{First Tree}

Men model (Fig1): The model yielded to a segmentation into 5 leaves. The strongest associated predictor of DoA was Area of Origin, with a split between all the areas except HoA and SSA. Quarter provided further splits among the subgroups. In the former branch (node 2) the 2018 quarters assessed 27.5\% 
probability of arriving with a disease (node $4, n=102$ ) while in the previous periods the frequency was lower (node 3, $n=1$ 038, $p=12.2 \%$ ). In the latter (node 5), a first split was performed between Q4/16, Q1/18, Q2/18 and the others (node 6, $n=3895, p=21.9 \%$ ). In node 7 Area of Origin determined another split between HoA (node 8, $n=543, p=46.2 \%$ ) and SSA (node 9, $n=2471, p=27.2 \%$ ).

Women model (Fig2): The model yielded to a segmentation into 3 leaves. The strongest predictor of DoA was Quarter: node 2 described the largest subgroup ( $n=978, p=17.7 \%$ ) of women, arrived in 2017 and Q3/16. As regards other quarters (no observations from East), Area of Origin determined a second split between HoA (node 5, $n=219, p=46.6 \%)$ and the remaining areas $(n=593, p=26.6 \%)$.

\subsection{Second Tree}

Men model (Figure 3): Quarter resulted to be the strongest predictor of the response variable. The model performed 4 terminal nodes. During Q3/16, Q3/17, Q4/17 (node 7, n=463) the most frequent diseases were of type A (33.7\%). On the other quarters branch (no obs. from CSA) a further split was performed by the variable Area of Origin: for arrivals from HoA, most diseases were included in category $\mathrm{S}(40 \%$ in $\mathrm{Q} 2 / 17$ and $\mathrm{Q} 4 / 16$, node $6, \mathrm{n}=145$ ), particularly in Q1/17, Q1/18, Q2/18 (node $5, \mathrm{n}=40, \mathrm{~S}=75 \%$ ). As regards the other areas (node $3, n=942$ ): $A=19.9 \%, D=16.1 \%$, Other $=20.9 \%, S=28.1 \%$.

Women model (Figure 4): Quarter was the only predictor of ICPC on arrival. The model performed a single split. For arrivals on Q3/16, Q2/17, Q3/17, Q4/17 (node 3, $\mathrm{n}=133$ ) the most frequent class of diseases was A (34.6\%) followed by Other (27.1\%). Regarding the other quarters (node $2, n=237$ ), the most frequent classes were S (33.8\%) and Other (25.3\%). No observations were detected from East, Middle East and NA.

\subsection{Third Tree}

Men model (Figure 5): The model yielded to a segmentation into 4 leaves. The strongest associated predictor was Quarter, with a split between 2017, Q2/18 (node 2) and the remaining quarters. For the last subgroup (node $7, n=4656$ ) the likelihood of developing a disease during the stay was very low $(5.7 \%)$. Quarter provided further splits in the first subgroup: Q1/17, Q/2/17 (node 3) and Q3/17, Q4/17, Q2/18 (node $6, n=1406,22.8 \%$ ). The former subgroup has been split again according to the variable Area of Origin, determining two terminal nodes: the sample from C.-S. Africa, Horn of Africa and Northern Africa had a probability of $17.8 \%$ of developing a disease (node $4, n=208$ ), whereas for arrivals from East, Middle East and Sub-Saharan Africa the prevalence was greater (node 5, n=1781, 36.4\%).

Women model (Figure 6): The splitting procedure resulted in 5 leaves and Quarter as the strongest predictor. The lowest probability (5.1\%) is observed for Q3/16 subgroup (node 6, $n=408$ ). In the remaining 2016 quarter the likelihood for women of age 35 and more was $36.1 \%$ (node $9, n=36$ ) while for the other age groups node 8 determined a probability equal to $11.9 \%$ (node $8, n=706$ ). In 2017 and 2018, a 50.9\% likelihood was found for the Sub-Saharan area (node 4, n=491), 30.1\% for the other areas (node 3, $n=153)$.

\subsection{Fourth Tree}


Men model (Figure 7): The algorithm generated a tree with 4 terminal nodes, in which the strongest predictor resulted to be Area of Origin. The Horn of Africa is split from the other areas, and this subgroup (node $7, n=106$ ) determined a probability of $32.1 \%$ to develop a type $S$ disease, while probabilities for other classes were lower. From other areas, the subgroup that arrived during Q3/16, Q2/17, Q3/17, Q4/17, Q1/18 (node 6, $n=639$ ) had $A$ as the most frequent class $(28.2 \%)$. For other quarters, a further split was performed according to the areas of origin: for arrivals from the Middle East (node 5, $n=65$ ) over half later diseases were of type $R(58.5 \%)$. For the remaining areas (node $4, n=432$ ) the most frequent class was $R$ as well $(32.2 \%)$, with all other classes around $17 \%$.

Women model (Figure 8): In the last model, the only associated variable (Quarter) carried out a single split generating two terminal nodes. For Q3/16, Q4/17, Q2/18 (node 3, $n=54$ ) the most frequent class was $D$ $(40.7 \%)$, followed by class Other (24.1\%), A (18.5\%), R (11.1\%) and S (5.6\%). In node 2 ( $n=355)$ class Other had the highest probability $(30.1 \%)(R=23.1 \%, A=17.7 \%, D=16.6 \%, S=12.4 \%)$.

Trees results were consistent with the logistic models (supplementary material).

\section{Discussion}

The present study describes the health status of ASs hosted in the centre "T. Fenoglio" between June 2016 and May 2018. Areas of arrival and differences in frequency among years reflect the overall history of migration towards Italy.

The ASs were young, mostly men from SSA. $24 \%$ arrived with at least one disease and the most frequent were dermatological, respiratory, digestive and generic diseases both on arrival and during the stay.

The probability of arriving with a disease resulted higher in 2018 and Q4/16, in particular for people from HoA. The health conditions worsening in 2018 could be caused by the more and more strict agreements between EU states and Libyan authorities: Italy has been one of the leading countries in providing assistance to the Libyan Coast Guard, in the attempt to limit arrivals. Eventually, Mediterranean departures have decreased since mid-2017, but the mortality rate increased from 1 in 42 in 2017 to 1 in 18 in 2018, according to UNHCR.[31]

During this period and also in the first half of 2017, the most reported diseases were dermatological. That is particularly true for men arrived from HoA, especially in Winters 2017-2018 (75\%). In quarters with lower prevalence of DoA the most common code was generic for both men and women (usually fever, in some cases trauma or not defined conditions).

HoA turned out to be a specific fragile subgroup especially regarding skin diseases. Probably that can be explained by observing the high prevalence of scabies. Rate of infection is reported to be even $80 \%$ for Eritrean arrivals[30] and $96.2 \%$ in a study on orphanages and two refugee camps in Sudan.[28] Skin diseases in general are caused by distinct factors in different stages of migration. Migrants crossing the Mediterranean Sea by boat are exposed for several days to extreme weather conditions, hygiene and food 
issues, chemical burns due to the contact with a mix of sea water and petrol.[28,34] Moreover, scabies results more prevalent in tropical countries: a review suggests that this can be due both to socioeconomic issues (low economic status, domestic crowding) and to the natural developing environment of scabies. [29]

Both the high skin diseases prevalence and the fact that population from HoA can be a more vulnerable subset of migrants have been found in other studies.[10,14] The route from HoA is much longer than those from East and Middle East: according to a survey held in Calais camp, for African refugees the median length of journey was 399, while it was between 46 and 90 for the other routes.[32] The main difference is determined by the prolonged stay in Libyan camps (median time 180 days), where the number of episodes of violence reported was very high, and it is virtually impossible to access health care.[32,33]

A comparison regarding DoA can be done with a study from NGOs that crossed the Mediterranean Sea during the same period. Distribution of areas of origin is similar and also diseases are comparable: the most frequent were scabies, respiratory and digestive infections.[12]

In a study from Malta, similar disease patterns are confirmed, using the ICD-9 code: skin, respiratory gastro-enteric and general were the most common diseases for a population mainly from East Africa.[24]

The first two quarters of 2017 resulted in the most problematic for diseases developed by men in the camp, in particular for people from East and SSA areas. A partial justification of observed differences can be found looking at the time of stay: the observations to our disposal suggest that in Q1/17 and Q2/17 the average time of stay is much longer than the 2016 average. A longer time in the camp can determine a higher likelihood of developing a disease or diagnosing one.

Despite that, it is important to remark that we have many missing observations regarding the time of stay and that could distort the results.

After arrival, for men from HoA the most common issue remained skin diseases: scabies was still present but mainly in attenuated forms (pruritus was the most reported condition). For the other areas respiratory problems increased, especially for Eastern and Middle Eastern ASs (59.4\% in Q1/17).

African women were at higher risk of developing a disease during all 2017/2018 quarters. For the women subgroup skin diseases were not the major problem, underlining a difference in the distribution of diseases by gender, while classes Digestive and Other were the most prevalent. In particular, the most common code for class Other was female genitals symptoms. Female ASs are often reported as a particularly fragile subpopulation, at high risk of suffering from sexual gender-based violence that cause a higher probability of physical and mental health consequences. This risk is particularly high for routes including Libya. This topic was treated in detail in another study from the same centre.[23]

Overall, the migrant population is heterogeneous,[26] and the associated literature can vary widely. Despite this, similar disease patterns can be found frequently. Other studies proved that the most 
common infectious conditions are respiratory, gastrointestinal, dermatological and also scabies infections are frequent. The spreading probability for this kind of diseases and other infection outbreaks are high when migrants are housed in crowded camps.[13,14,21]

Respiratory diseases are a particular burden because migrants are vulnerable to antimicrobial resistance, susceptible to influenza for low levels of vaccination, and subject to different pulmonary infections and parasitic diseases such as strongyloidiasis and paragonimiasis. Prevalence in migrants often refers to the endemic situation in countries of origin.[18]

In different studies that involved mainly arrivals from the Eastern routes toward camps and clinics in Greece (32\% Syrians), Brussels (50\% from Iraq) and Dresden (classified with ICD-10 code) the main diseases were respiratory.[15,16,25]

A study on migrants hosted in Augusta (2014) highlighted the heterogeneity of this population by comparing arrivals from the near eastern war zones and Africa. The latter group is composed of young men with higher prevalence of skin diseases ( $95 \%$ of scabies cases out of the total sample). However, respiratory, dermatological, gastrointestinal and trauma conditions had a similar likelihood in both groups.[17]

A study on the centre of Castelnuovo di Porto (Rome) reported respiratory diseases as the most common, while prevalence of skin diseases was lower. This can be due to the fact that the population distribution was different (major group was from Pakistan).[11]

We found very low rates in mental illness and psychological distress despite those being considered a major problem for ASs and migrants in general.[19,22,27] Nevertheless, different studies showed a struggle in treating these conditions and an inadequate utilization of care structures. This is caused by different factors among which many social and cultural barriers.[19,21-26] In addition, a lower rate in psychological disorders may be due to somatization.[24] Pain general diagnoses (A01) can be brought back to this kind of disorders: in our sample we found 61 cases on arrival (2.88\%) and $168(9.45 \%)$ during the stay.

\section{Conclusion}

The study has several limitations: selection bias can be observed because many records were incomplete or missing. Also, the reception path for unaccompanied minors and people victim of violence or abuse was different, and that can partly affect the very low prevalence of mental diseases. The median time of stay was low (10 days) and that can determine an underestimation of diseases after arrival as well as an incorrect estimate of the distributions of different disease types.

Despite this, we can bring some results on a very large sample of ASs, which contains representatives from 47 countries and all the typical routes towards Italy. HoA resulted in the most troubled area with severe conditions regarding skin diseases, in particular scabies. 2018 resulted the most dangerous year, 
especially from HoA and SSA and that can be associated with EU and Italian choices of borders policy. After arrival, the distribution of the diseases aligned with that of different studies from non-African routes, highlighting that respiratory diseases are quite common (but also skin, dermatological and digestive diseases are present).

\section{Declarations}

\section{Ethics approval and consent to participate}

The study has been reported to the Bioethics Committee of the University of Turin.

\section{Consent for publication}

Not applicable.

\section{Availability of data and materials}

The datasets used and analyzed during the current study are available from the corresponding author.

\section{Authors contributions}

L.M.: study design, data analysis, article writing. F.R., C.S..study design, article review. V.S., M.P., G.C., R.R.P.: data collection, article review. C.D., R.G., A.M.,A.C.: critical manuscript review.

\section{Competing interests}

The authors declare that they have no competing interests related to the content of this article.

\section{Funding}

None.

\section{Acknowledgements}

Not applicable.

\section{References}

1. https://www.unhcr.org/refugee-statistics/

2. UN High Commissioner for Refugees (UNHCR), UNHCR Master Glossary of Terms, June 2006, Rev.1

3. https://www.europarl.europa.eu/news/en/headlines/society/20170629ST078630/asylum-andmigration-in-the-eu-facts-and-figures 
4. https://ec.europa.eu/eurostat/statistics-explained/index.php? 20title=Asylum_statistics\#Citizenship_of_first-time_applicants: 20_largest_numbers_from_Syria.2C_Afghanistan_and_Venezuela

5. https://data2.unhcr.org/en/situations/mediterranean/location/5205

6. https://ec.europa.eu/home-affairs/what-we-do/policies/asylum/examination-of-applicants_en

7. https://www.unhcr.org/it/cosa-facciamo/protezione/diritto-asilo/italia/legislazione/

8. https://www.who.int/standards/classifications/other-classifications/international-classificationof-primary-care

9. https://www.zeileis.org/papers/Hothorn+Hornik+Zeileis-2006.pdf

10. Di Meco E., Di Napoli A., Amato L. M., Fortino A., Costanzo G., Rossi A., Mirisola C. and Petrelli A. (2018). Infectious and dermatological diseases among arriving migrants on the Italian coasts European Journal of Public Health, Volume 28; https://doi.org/10.1093/eurpub/cky126.

11. Russo G., Vita S., Miglietta A., Terrazzini N., Sannella A. and Vullo V. (2016). Health profile and disease determinants among asylum see- kers: a cross-sectional retrospective study from an Italian reception centre.Journal of Public Health, Volume 38; https://doi.org/10.1093/pubmed/fdv049.

12. Cañardo G., Gálvez J., Jiménez J., Serre N., Molina I. and Bocanegra C. (2020). Health status of rescued people by the NGO Open Arms in response to the refugee crisis in the Mediterranean Sea. Conflict and Health Volume 14; https://doi.org/10.1186/s13031-020-00275-z.

13. Vairo F., Di Bari V., Panella V., Quintavalle G., Torchia S., Serra M.C., Sinopoli M.T., Lopalco M., Ceccarelli G., Ferraro F., Valle S., Bordi L., Capobianchi M.R., Puro V., Scognamiglio P. and Ippolito G. (2017). An outbreak of chickenpox in an asylum seeker centre in Italy: outbreak investigation and validity of reported chickenpox history, December 2015-May 2016. Eurosurveillance.

14. Greenaway C. and Castelli F. (2019). Infectious diseases at different stages of migration: an expert review Journal of Travel Medicine, Volume 26; https://doi.org/10.1093/jtm/taz007.

15. Hermans M.P.J., Kooistra J., Cannegieter S.C., Rosendaal F.R., Mook- Kanamori D.O. and Nemeth B. (2017). Healthcare and disease burden among refugees in long-stay refugee camps at Lesbos, Greece. European Journal of Epidemiology, Volume 32; https://doi.org/10.1007/s10654017-0269-4.

16. Van Berlaer G., Carbonell F.B., Manantsoa S., De Bethune X., Buyl R., Debacker M. and Hubloue I. (2016). A refugee camp in the centre of Eu- rope: clinical characteristics of asylum seekers arriving in Brussels. BMJ Open, Volume 6; http://dx.doi.org/10.1136/bmjopen-2016-013963.

17. Trovato A., Reid A., Takandra C.K., Montaldo C., Decroo T., Owiti P., Bongiorno F. and Di Carlo S. (2016). Dangerous crossing: demographic and clinical features of rescued sea migrants seen in 2014 at an outpatient clinic at Augusta Harbor, Italy. Conflict and Health, Volume 10; https://doi.org/10.1186/s13031-016-0080-y.

18. Olaru I.D., Van Den Broucke S., Rosser A.J., Salzer J.F.H., Woltmann G., Bottieau E., Lange C. (2018). Pulmonary Diseases in Refugees and Migrants in Europe. Respiration, Volume 95; 
https://doi.org/10.1159/000486451.

19. Abbott A. (2016). The troubled minds of migrants. Nature, Volume 538.

20. Satinsky E., Fuhr D.C., Woodward A., Sondorp E., Roberts B. (2019). Mental health care utilisation and access among refugees and asylum see- kers in Europe: A systematic review. Health Policy, Volume 123; https://doi.org/10.1016/j.healthpol.2019.02.007.

21. Pavli A., Maltezou H. (2017). Health problems of newly arrived migrants and refugees in Europe. Journal of Travel Medicine, Volume 24; https://doi.org/10.1093/jtm/tax016.

22. Firenze A., Aleo N., Ferrara C., Maranto M., La Cascia C., Restivo V. (2016). The occurrence of diseases and related factors in a centre for asylum seekers in Italy. Zdrav Var, Volume 55.

23. Bronsino M., Castagneri C, Spinazzola M., Pepe R.R., Sacerdote C., Ricceri F. (2020). "Journey of hope": a study on sexual gender-based violence reported by asylum-seeking women during their journey to Europe. Epidemiologia e Prevenzione, Volume 44; https://doi.org/10.19191/EP20.56.S1.P102.079.

24. Padovese V., Egidi A.M., Melillo Fenech T., Connor M.P., Didero D., Co-stanzo G., Mirisola C. (2013). Migrations and determinants of health: clinical epidemiological characteristics of migrants in Malta (2010-11). Journal of Public Health, Volume 36; https://doi.org/10.1093/pubmed/fdt111.

25. Goodman L.F., Jensen G.W., Galante J.M., Farmer D.L. and Taché S. (2018). A cross-sectional investigation of the health needs of asylum seekers in a refugee clinic in Germany. BMC Family Practice, Volume 19; https://doi.org/10.1186/s12875-018-0758-x.

26. De Vito E., De Ware C., Specchia M. L. and Ricciardi W. (WHO, 2015). Public health aspects of migrant health: a review of the evidence on health status for undocumented migrants in the European Region. Health Evidence Network Synthesis Report, 42

27. World Health Organization (WHO). Report on the health of refugees and migrants in the WHO European Region.

28. Padovese V., Knapp A. (2021). Challenges of Managing Skin Diseases in Refugees and Migrants. Dermatologic Clinics, Volume 39; https://doi.org/10.1016/j.det.2020.08.010.

29. Romani L., Steer A.C., Whitfeld M.J., Kaldor J.M. (2015). Prevalence of scabies and impetigo worldwide: a systematic review. The Lancet Infectious Diseases, Volume 15; https://doi.org/10.1016/S1473-3099(15)00132-2.

30. Isenring E., Fehr J., Gültekin N., Schlagenhauf P. (2018). Infectious di- seases profiles of Syrian and Eritrean migrants presenting in Europe: A systematic review. Travel Medicine and Infectious Diseases, Volume 25; https://doi.org/10.1016/j.tmaid.2018.04.014.

31. https://www.hrw.org/report/2019/01/21/no-escape-hell/eu-policies-contribute-abuse-mig

32. Bouhenia M., Farahat J.B., Coldiron M.E., Abdallah S., Visentin D., Neu- man M., Berthelot M., Porten K. and Cohuet S. (2017). Quantitative survey on health and violence endured by refugees during their journey and in Calais, France. International Health, Volume 9; https://doi.org/10.1093/inthealth/ihx040. 
33. Reques L., Aranda-Fernandez E., Rolland C., Grippon A., Fallet N., Re- boul C., Godard N. and Luhmann N. (2020). Episodes of violence suffered by migrants transiting through Libya: a crosssectional study in "Méde- cins du Monde's" reception and healthcare centre in Seine-Saint-Denis, France. Conflict and Health, Volume 14; https://doi.org/10.1186/s13031-020-0256-3.

34. Ricceri F., Sciannameo V., De Michelis F., Perucca L., Mondo L., Pepe R.R., Sacerdote C. (2018). Prevalence of acid burns among asylum seekers hosted in an initial reception centre as an example of health assessment in a fragile population. Epidemiologia e Prevenzione, Volume 42; https://doi.org/10.19191/EP18.2.P134.042.

35. R Core Team. R: A language and environment for statistical computing. R Foundation for Statistical Computing. Vienna, Austria; 2019. Available from: https://www.R-project.org

\section{Tables}

Table1. Socio-Demographic Variables 


\begin{tabular}{|c|c|c|c|c|c|c|c|}
\hline Variables & & Female & & Male & & Total & \\
\hline & Categories & $\mathrm{n}$ & $\%$ & $\mathrm{n}$ & $\%$ & $\mathrm{n}$ & $\%$ \\
\hline \multirow[t]{8}{*}{ Area of Origin } & Sub-Saharan Africa & 1242 & $72.04 \%$ & 5687 & $70.53 \%$ & 6929 & $70.31 \%$ \\
\hline & Central-Southern Africa & 24 & $1.39 \%$ & 39 & $0.48 \%$ & 63 & $0.64 \%$ \\
\hline & Horn of Africa & 437 & $25.35 \%$ & 1227 & $15.22 \%$ & 1664 & $16.88 \%$ \\
\hline & Middle East & 30 & $1.74 \%$ & 538 & $6.67 \%$ & 568 & $5.76 \%$ \\
\hline & Northern Africa & 60 & $3.48 \%$ & 114 & $1.41 \%$ & 174 & $1.77 \%$ \\
\hline & East & 1 & $0.06 \%$ & 456 & $5.66 \%$ & 457 & $4.64 \%$ \\
\hline & Total & 1794 & $100 \%$ & 8063 & $100 \%$ & 9855 & $100 \%$ \\
\hline & missing & & & & & 2 & \\
\hline \multirow[t]{5}{*}{ Age Group } & $18-24$ & 1124 & $62.65 \%$ & 5066 & $62.83 \%$ & 6190 & $62.80 \%$ \\
\hline & $25-34$ & 557 & $31.05 \%$ & 2463 & $30.55 \%$ & 3020 & $30.64 \%$ \\
\hline & $35+$ & 113 & $6.30 \%$ & 534 & $6.62 \%$ & 647 & $6.56 \%$ \\
\hline & Total & 1794 & $100 \%$ & 8063 & $100 \%$ & 9857 & $100 \%$ \\
\hline & missing & & & & & & \\
\hline \multirow[t]{6}{*}{ Quarter } & $\begin{array}{l}\text { June-August } 2016 \\
(\mathrm{Q} 3 / 16)\end{array}$ & 408 & $22.74 \%$ & 1368 & $16.97 \%$ & 1776 & $18.02 \%$ \\
\hline & Q4/16 & 742 & $41.36 \%$ & 3061 & $37.96 \%$ & 3803 & $38.58 \%$ \\
\hline & Q1/17 & 146 & $8.14 \%$ & 1023 & $12.69 \%$ & 1169 & $11.86 \%$ \\
\hline & Q2/17 & 155 & $8.64 \%$ & 966 & $11.98 \%$ & 1121 & $11.37 \%$ \\
\hline & Q3/17 & 206 & $11.48 \%$ & 966 & $11.98 \%$ & 1172 & $11.89 \%$ \\
\hline & Q4/17 & 66 & $3.68 \%$ & 289 & $3.58 \%$ & 355 & $3.60 \%$ \\
\hline & & & & & & & \\
\hline
\end{tabular}




\begin{tabular}{|l|l|l|l|l|l|l|l|} 
& Q1/18 & 57 & $3.18 \%$ & 228 & $2.83 \%$ & 285 & $2.89 \%$ \\
\hline & Q2/18 & 14 & $0.78 \%$ & 153 & $1.90 \%$ & 167 & $1.69 \%$ \\
\hline & Total & 1794 & $100 \%$ & 8054 & $100 \%$ & 9848 & $100 \%$ \\
\hline & missing & & & & & 9 & \\
\hline
\end{tabular}

Table2. Diseases on Arrival 


\begin{tabular}{|c|c|c|c|c|c|c|c|}
\hline & Female & & & Male & & & Total \\
\hline Classes & $18-24$ & $25-34$ & $35+$ & $18-24$ & $25-34$ & $35+$ & \\
\hline & $\begin{array}{l}\mathrm{n} \\
(\%)\end{array}$ & $\begin{array}{l}\mathrm{n} \\
(\%)\end{array}$ & $\begin{array}{l}\mathrm{n} \\
(\%)\end{array}$ & $\begin{array}{l}\mathrm{n} \\
(\%)\end{array}$ & $\begin{array}{l}\mathrm{n} \\
(\%)\end{array}$ & $\begin{array}{l}\mathrm{n} \\
(\%)\end{array}$ & $\begin{array}{l}\mathrm{n} \\
(\%)\end{array}$ \\
\hline General (A) & $\begin{array}{l}56 \\
(20.51)\end{array}$ & $\begin{array}{l}24 \\
(18.75)\end{array}$ & $\begin{array}{l}5 \\
(19.23)\end{array}$ & $248(22.57)$ & $104(18.21)$ & $\begin{array}{l}28 \\
(21.54)\end{array}$ & 465 (20.88) \\
\hline B & $\begin{array}{l}5 \\
(1.83)\end{array}$ & $\begin{array}{l}1 \\
(0.78)\end{array}$ & . & $\begin{array}{l}7 \\
(0.64)\end{array}$ & $\begin{array}{l}7 \\
(1.23)\end{array}$ & . & $\begin{array}{l}20 \\
(0.90)\end{array}$ \\
\hline $\mathrm{D}$ & $\begin{array}{l}46 \\
(16.85)\end{array}$ & 11 (8.59) & $\begin{array}{l}3 \\
(11.54)\end{array}$ & 161 (14.65) & $\begin{array}{l}95 \\
(16.64)\end{array}$ & $\begin{array}{l}12 \\
(9.23)\end{array}$ & 328 (14.73) \\
\hline $\mathrm{F}$ & $\begin{array}{l}4 \\
(1.47)\end{array}$ & $\begin{array}{l}1 \\
(0.78)\end{array}$ & $\begin{array}{l}1 \\
(3.85)\end{array}$ & $\begin{array}{l}24 \\
(2.18)\end{array}$ & $\begin{array}{l}11 \\
(1.93)\end{array}$ & $\begin{array}{l}2 \\
(1.54)\end{array}$ & $\begin{array}{l}43 \\
(1.93)\end{array}$ \\
\hline $\mathrm{H}$ & . & . & . & $\begin{array}{l}13 \\
(1.18)\end{array}$ & $\begin{array}{l}4 \\
(0.70)\end{array}$ & $\begin{array}{l}1 \\
(0.77)\end{array}$ & $\begin{array}{l}18 \\
(0.81)\end{array}$ \\
\hline K & $\begin{array}{l}2 \\
(0.73)\end{array}$ & $\begin{array}{l}5 \\
(3.91)\end{array}$ & . & $\begin{array}{l}15 \\
(1.36)\end{array}$ & $14(2.45)$ & $\begin{array}{l}7 \\
\text { (5.38) }\end{array}$ & $\begin{array}{l}43 \\
(1.93)\end{array}$ \\
\hline $\mathrm{L}$ & $\begin{array}{l}6 \\
(2.20)\end{array}$ & $\begin{array}{l}18 \\
(14.06)\end{array}$ & $\begin{array}{l}4 \\
(15.38)\end{array}$ & $\begin{array}{l}81 \\
(7.37)\end{array}$ & $\begin{array}{l}55 \\
(9.63)\end{array}$ & $\begin{array}{l}17 \\
(13.08)\end{array}$ & $\begin{array}{l}181 \\
(8.813)\end{array}$ \\
\hline $\mathrm{N}$ & $\begin{array}{l}12 \\
(4.40)\end{array}$ & $\begin{array}{l}3 \\
(2.34)\end{array}$ & $\begin{array}{l}2 \\
(7.69)\end{array}$ & $\begin{array}{l}29 \\
(2.64)\end{array}$ & $\begin{array}{l}12 \\
(2.10)\end{array}$ & $\begin{array}{l}5 \\
(3.85)\end{array}$ & $\begin{array}{l}63 \\
(2.83)\end{array}$ \\
\hline $\mathrm{P}$ & $\begin{array}{l}4 \\
(1.47)\end{array}$ & $\begin{array}{l}1 \\
(0.78)\end{array}$ & . & $\begin{array}{l}7 \\
(0.64)\end{array}$ & $\begin{array}{l}11 \\
(1.93)\end{array}$ & $\begin{array}{l}1 \\
(0.77)\end{array}$ & $\begin{array}{l}24 \\
(1.08)\end{array}$ \\
\hline $\mathrm{R}$ & $\begin{array}{l}35 \\
(12.28)\end{array}$ & $\begin{array}{l}18 \\
(14.06)\end{array}$ & $\begin{array}{l}4 \\
(15.38)\end{array}$ & $151(13.74)$ & $\begin{array}{l}91 \\
(15.94)\end{array}$ & $\begin{array}{l}23 \\
(17.69)\end{array}$ & 322 (14.46) \\
\hline S & $\begin{array}{l}70 \\
(25.64)\end{array}$ & $\begin{array}{l}38 \\
(29.69)\end{array}$ & $\begin{array}{l}5 \\
(19.23)\end{array}$ & 329 (29.94) & $146(25.57)$ & $\begin{array}{l}29 \\
(22.31)\end{array}$ & $617(27.71)$ \\
\hline
\end{tabular}




\begin{tabular}{|c|c|c|c|c|c|c|c|}
\hline $\mathrm{T}$ & . & $\begin{array}{l}1 \\
(0.78)\end{array}$ & $\begin{array}{l}2 \\
(7.69)\end{array}$ & $\begin{array}{l}1 \\
(0.09)\end{array}$ & $\begin{array}{l}3 \\
(0.53)\end{array}$ & $\begin{array}{l}3 \\
(2.31)\end{array}$ & $\begin{array}{l}10 \\
(0.45)\end{array}$ \\
\hline $\mathrm{U}$ & $\begin{array}{l}2 \\
(0.73)\end{array}$ & $\begin{array}{l}1 \\
(0.78)\end{array}$ & . & $\begin{array}{l}9 \\
(0.82)\end{array}$ & $\begin{array}{l}9 \\
(1.58)\end{array}$ & . & $\begin{array}{l}21 \\
(0.94)\end{array}$ \\
\hline W & $\begin{array}{l}2 \\
(0.73)\end{array}$ & . & . & . & . & & $\begin{array}{l}2 \\
(0.09)\end{array}$ \\
\hline $\mathrm{X}$ & $\begin{array}{l}29 \\
(4.69)\end{array}$ & $\begin{array}{l}6 \\
(4.69)\end{array}$ & . & . & . & . & $\begin{array}{l}35 \\
(1.57)\end{array}$ \\
\hline $\mathrm{Y}$ & . & . & . & $\begin{array}{l}24 \\
(2.18)\end{array}$ & $\begin{array}{l}9 \\
(1.58)\end{array}$ & $\begin{array}{l}2 \\
(1.54)\end{array}$ & $\begin{array}{l}35 \\
(1.57)\end{array}$ \\
\hline
\end{tabular}

Table 3. Diseases after Arrival 


\begin{tabular}{|c|c|c|c|c|c|c|c|}
\hline & Female & & & Male & & & Total \\
\hline Classes & $18-24$ & $25-34$ & $35+$ & $18-24$ & $25-34$ & $35+$ & \\
\hline & $\begin{array}{l}\mathrm{n} \\
(\%)\end{array}$ & $\begin{array}{l}\mathrm{n} \\
(\%)\end{array}$ & $\begin{array}{l}\mathrm{n} \\
(\%)\end{array}$ & $\begin{array}{l}\mathrm{n} \\
(\%)\end{array}$ & $\begin{array}{l}\mathrm{n} \\
(\%)\end{array}$ & $\begin{array}{l}\mathrm{n} \\
(\%)\end{array}$ & $\begin{array}{l}\mathrm{n} \\
(\%)\end{array}$ \\
\hline A & $\begin{array}{l}66 \\
(16.84)\end{array}$ & $\begin{array}{l}46 \\
(20.44)\end{array}$ & $\begin{array}{l}11 \\
(17.46)\end{array}$ & $246(23.12)$ & 144 (23.19) & $\begin{array}{l}29 \\
(23.19)\end{array}$ & $\begin{array}{l}513 \\
(21.56)\end{array}$ \\
\hline B & . & . & . & $\begin{array}{l}1 \\
(0.09)\end{array}$ & $\begin{array}{l}1 \\
(0.16)\end{array}$ & $\begin{array}{l}1 \\
(0.67)\end{array}$ & $\begin{array}{l}2 \\
(0.12)\end{array}$ \\
\hline $\mathrm{D}$ & $\begin{array}{l}94 \\
(23.98)\end{array}$ & $\begin{array}{l}45 \\
(20)\end{array}$ & $\begin{array}{l}6 \\
(9.52)\end{array}$ & $174(16.35)$ & $\begin{array}{l}90 \\
(14.49)\end{array}$ & $\begin{array}{l}17 \\
(11.41)\end{array}$ & 409 (16.95) \\
\hline $\mathrm{F}$ & $\begin{array}{l}5 \\
(1.28)\end{array}$ & $\begin{array}{l}4 \\
(1.78)\end{array}$ & $\begin{array}{l}3 \\
(4.76)\end{array}$ & $\begin{array}{l}18 \\
(1.69)\end{array}$ & $\begin{array}{l}18 \\
(2.90)\end{array}$ & $\begin{array}{l}5 \\
(3.36)\end{array}$ & $\begin{array}{l}48 \\
(2.11)\end{array}$ \\
\hline $\mathrm{H}$ & $\begin{array}{l}6 \\
(1.53)\end{array}$ & $\begin{array}{l}2 \\
(0.89)\end{array}$ & $\begin{array}{l}1 \\
(1.59)\end{array}$ & $\begin{array}{l}9 \\
(0.85)\end{array}$ & $\begin{array}{l}9 \\
(1.45)\end{array}$ & . & $\begin{array}{l}27 \\
(1.07)\end{array}$ \\
\hline K & $\begin{array}{l}1 \\
(0.26)\end{array}$ & $\begin{array}{l}2 \\
(0.89)\end{array}$ & $\begin{array}{l}2 \\
(3.17)\end{array}$ & $\begin{array}{l}6 \\
(0.56)\end{array}$ & $\begin{array}{l}8 \\
(1.29)\end{array}$ & . & $\begin{array}{l}19 \\
(0.76)\end{array}$ \\
\hline $\mathrm{L}$ & $\begin{array}{l}8 \\
(2.04)\end{array}$ & $\begin{array}{l}13 \\
(5.78)\end{array}$ & $\begin{array}{l}6 \\
(9.52)\end{array}$ & $\begin{array}{l}60 \\
(5.64)\end{array}$ & $\begin{array}{l}45 \\
(7.25)\end{array}$ & $\begin{array}{l}9 \\
(6.04)\end{array}$ & $\begin{array}{l}132 \\
(5.61)\end{array}$ \\
\hline $\mathrm{N}$ & $\begin{array}{l}27 \\
(6.89)\end{array}$ & $\begin{array}{l}17 \\
(7.56)\end{array}$ & $\begin{array}{l}4 \\
(6.35)\end{array}$ & $\begin{array}{l}66 \\
(6.20)\end{array}$ & $\begin{array}{l}32 \\
(5.15)\end{array}$ & $\begin{array}{l}10 \\
(6.71)\end{array}$ & $\begin{array}{l}146 \\
(6.21)\end{array}$ \\
\hline $\mathrm{P}$ & $\begin{array}{l}7 \\
(1.79)\end{array}$ & $\begin{array}{l}3 \\
(1.33)\end{array}$ & $\begin{array}{l}2 \\
(3.17)\end{array}$ & $\begin{array}{l}12 \\
(1.13)\end{array}$ & $\begin{array}{l}5 \\
(0.81)\end{array}$ & $\begin{array}{l}2 \\
(1.34)\end{array}$ & $\begin{array}{l}29 \\
(1.23)\end{array}$ \\
\hline $\mathrm{R}$ & $\begin{array}{l}67 \\
(17.09)\end{array}$ & $\begin{array}{l}40 \\
(17.78)\end{array}$ & $\begin{array}{l}17 \\
(26.98)\end{array}$ & $289(27.16)$ & $174(28.02)$ & $\begin{array}{l}59 \\
(39.60)\end{array}$ & $\begin{array}{l}587 \\
(25.70)\end{array}$ \\
\hline S & $\begin{array}{l}38 \\
(9.69)\end{array}$ & $\begin{array}{l}21 \\
(9.33)\end{array}$ & $\begin{array}{l}8 \\
(12.70)\end{array}$ & $154(14.47)$ & $\begin{array}{l}77 \\
(12.40)\end{array}$ & $\begin{array}{l}11 \\
(7.38)\end{array}$ & $\begin{array}{l}298 \\
(12.29)\end{array}$ \\
\hline
\end{tabular}




\begin{tabular}{|c|c|c|c|c|c|c|c|}
\hline $\mathrm{T}$ & $\begin{array}{l}4 \\
(1.02)\end{array}$ & . & $\begin{array}{l}2 \\
(3.17)\end{array}$ & $\begin{array}{l}1 \\
(0.89)\end{array}$ & $\begin{array}{l}1 \\
(0.16)\end{array}$ & $\begin{array}{l}1 \\
(0.67)\end{array}$ & $\begin{array}{l}8 \\
(0.36)\end{array}$ \\
\hline $\mathrm{U}$ & $\begin{array}{l}12 \\
(3.06)\end{array}$ & $\begin{array}{l}5 \\
(2.22)\end{array}$ & & $\begin{array}{l}18 \\
(1.69)\end{array}$ & $\begin{array}{l}13 \\
(2.09)\end{array}$ & $\begin{array}{l}3 \\
(2.01)\end{array}$ & $\begin{array}{l}48 \\
(2.03)\end{array}$ \\
\hline $\mathrm{W}$ & $\begin{array}{l}11 \\
(2.81)\end{array}$ & $\begin{array}{l}5 \\
(2.22)\end{array}$ & & . & . & . & $\begin{array}{l}16 \\
(0.64)\end{array}$ \\
\hline$X$ & $\begin{array}{l}46 \\
(11.73)\end{array}$ & $\begin{array}{l}22 \\
(9.78)\end{array}$ & $\begin{array}{l}1 \\
(1.59)\end{array}$ & . & . & . & $\begin{array}{l}69 \\
(2.74)\end{array}$ \\
\hline$Y$ & . & . & & $\begin{array}{l}10 \\
(0.94)\end{array}$ & $\begin{array}{l}4 \\
(0.64)\end{array}$ & $\begin{array}{l}2 \\
(1.34)\end{array}$ & $\begin{array}{l}14 \\
(0.64)\end{array}$ \\
\hline
\end{tabular}

\section{Figures}

\section{Figure 1}

Men model (Fig1): The model yielded to a segmentation into 5 leaves. The strongest associated predictor of DoA was Area of Origin, with a split between all the areas except HoA and SSA.

\section{Figure 2}

Women model (Fig2): The model yielded to a segmentation into 3 leaves. The strongest predictor of DoA was Quarter: node 2 described the largest subgroup ( $n=978, p=17.7 \%$ ) of women, arrived in 2017 and Q3/16. As regards other quarters (no observations from East), Area of Origin determined a second split between HoA (node 5, $n=219, p=46.6 \%)$ and the remaining areas $(n=593, p=26.6 \%)$.

\section{Figure 3}

Men model (Figure 3): Quarter resulted to be the strongest predictor of the response variable. The model performed 4 terminal nodes. During Q3/16, Q3/17, Q4/17 (node 7, n=463) the most frequent diseases were of type $A(33.7 \%)$. 


\section{Figure 4}

Women model (Figure 4): Quarter was the only predictor of ICPC on arrival. The model performed a single split. For arrivals on Q3/16, Q2/17, Q3/17, Q4/17 (node 3, $n=133$ ) the most frequent class of diseases was A (34.6\%) followed by Other (27.1\%). Regarding the other quarters (node 2, n=237), the most frequent classes were S (33.8\%) and Other (25.3\%). No observations were detected from East, Middle East and NA.

\section{Figure 5}

Men model (Figure 5): The model yielded to a segmentation into 4 leaves. The strongest associated predictor was Quarter, with a split between 2017, Q2/18 (node 2) and the remaining quarters.

\section{Figure 6}

Women model (Figure 6): The splitting procedure resulted in 5 leaves and Quarter as the strongest predictor.

\section{Figure 7}

Men model (Figure 7): The algorithm generated a tree with 4 terminal nodes, in which the strongest predictor resulted to be Area of Origin.

\section{Figure 8}

Women model (Figure 8): In the last model, the only associated variable (Quarter) carried out a single split generating two terminal nodes. For Q3/16, Q4/17, Q2/18 (node 3, $n=54$ ) the most frequent class was $D$ (40.7\%), followed by class Other (24.1\%), A (18.5\%), R (11.1\%) and S (5.6\%). In node 2 ( $n=355)$ class Other had the highest probability (30.1\%) $(R=23.1 \%, A=17.7 \%, D=16.6 \%, S=12.4 \%)$.

\section{Supplementary Files}

This is a list of supplementary files associated with this preprint. Click to download.

- SupplementaryMaterial.docx 